Research Report No. 37/2012

\title{
Oppression, Suppression, and Injustice: A Critical Evaluation of the Grievance Procedure in the Federal Public Service
}

Grant LoPatriello

Follow this and additional works at: http:// digitalcommons.osgoode.yorku.ca/clpe

\section{Recommended Citation}

LoPatriello, Grant, "Oppression, Suppression, and Injustice: A Critical Evaluation of the Grievance Procedure in the Federal Public Service" (2012). Comparative Research in Law \& Political Economy. Research Paper No. 37/2012.

http://digitalcommons.osgoode.yorku.ca/clpe/13 


\section{OSGOODE}

OSGOODE HALL LAW SCHOOL YORK UNIVERSITY

\section{OSGOODE HALL LAW SCHOOL}

Comparative Research in Law \& Political Economy

RESEARCH PAPER SERIES

Research Paper No. 37/2012

Oppression, suppression, and injustice A critical evaluation of the grievance procedure in the federal public service

Grant LoPatriello

\section{Editors:}

Peer Zumbansen (Osgoode Hall Law School, Toronto, Director Comparative Research in Law and Political Economy)

John W. Cioffi (University of California at Riverside)

Leeanne Footman (Osgoode Hall Law School, Toronto, Production Editor)

Comparative Research in Law \& Political Economy 


\section{OSGOODE}

OSGOODE HALL LAW SCHOOL

YORK UNIVERSITY

\section{Oppression, suppression, and injustice}

\section{A critical evaluation of the grievance procedure in the federal public service}

As presented at the 49th annual conference of the

Canadian Industrial Relations Association

Grant LoPatriello (@osgoode.yorku.ca) 
This page intentionally left blank. 


\section{Introduction}

The year 1967 brought about a major change to the manner in which employer-employee conflicts could be resolved in Canada's federal public service. Indeed, the Public Service Staff Relations $A c t^{1}$ established a procedure for the articulation and resolution of employee-centred grievances. Thus, for the first time in the history of Canada's public service, employees could grieve any matter arising from the administration of any federal statute, as well as any provision of an applicable collective agreement. ${ }^{2}$ This advancement in the public service collective bargaining regime was a resounding accomplishment, as "the doctrine of sovereignty for years provided top management with what appeared to be an impregnable rationalization for refusing to concede even a modicum of the claims urged on them by employees."3

The grievance procedure that was adopted by the Government of Canada in 1967 resembles the relatively informal procedures that were — and still remain — available to employees covered by collective agreements in the private sector. ${ }^{4}$ However, there is one major difference: The government model is far more formal - both in substance, and in form. And, whether this difference was intended is immaterial; it carries with it detrimental consequences. The formality and rigidity with which the grievance procedure is applied not only undermines the goals of the informal model — the model upon which the public sector procedure was based — but also its values. The adversarial nature of the procedure discourages, for example, a collegial, bilateral dialogue between the aggrieved employee and management - the cornerstone of any effective grievance procedure. Moreover, fairness, timeliness, flexibility, and reasonableness are, at best,

\footnotetext{
${ }^{1}$ S.C. 1967 , c. 72 .

${ }^{2}$ Although s.68 (1) (s) of the Civil Service Act, S.C. 1961, c. 57 refers to a "procedure for dealing with grievances," such a procedure was not effective until the enactment of the Public Service Staff Relations Act, ibid.

${ }^{3}$ J.E. Hodgetts, The Canadian Public Service: A Physiology of Government 1867-1970 (Toronto: University of Toronto Press, 1973) at 311.

${ }^{4}$ Canada, Report of the Preparatory Committee on Collective Bargaining in the Public Service (Ottawa: Queen's Printer, 1965) at 38 (Chair: A.D.P. Heeney).
} 
elusive concepts under the formal model. Accordingly, the benefits that are expected to be derived from the procedure cannot be realized when it is applied with such rigour. In fact, the grievance procedure that was available to the federal public service had counter-productive effects: It robbed employees of workplace participation and industrial democracy, while simultaneously providing the illusion of a democratic and rights-based forum in which to resolve conflict. In other words, the Government of Canada model did very little in the way of resolving employee-centred grievances.

Although the grievance procedure lives on today under the Public Service Labour Relations $A c t,{ }^{5}$ little change has been effected, despite the numerous recommendations of various government-established committees. ${ }^{6}$ In fact, the text of both the 1967 Act, and the collective agreements that were negotiated subsequent to its enactment, ${ }^{7}$ are almost identical to the Act and collective agreements that govern the grievance procedure today. Thus, the core values that should be espoused by the procedure remain, in many instances, far-removed from its application—-leaving conflicts unresolved, and aggrieved parties further aggravated.

Alas, the problems that arise in the course of administering the grievance procedure are not confined to the individual grievance. The "formal administrative process" $" 8$ also presents a number of systemic problems. Because of its formal nature, the grievance procedure duplicates the work of the Public Service Labour Relations Board, without having the added benefit of its

\footnotetext{
${ }^{5}$ S.C. 2003 , c. 22.

${ }^{6}$ See e.g. Canada, Public Service Advisory Council, Recourse in the Public Service of Canada: Report of the Public Service Commission Advisory Council's Working Group on Recourse (Ottawa: Communication Group, 2001) [Report on Recourse], and Canada, Treasury Board of Canada Secretariat, Final Report of the Advisory Committee on Labour Management Relations in the Federal Public Service (Ottawa: Communication Group, 2001) (Chair: John L. Fryer) [Fryer Report].

${ }^{7}$ See e.g. Agreement between the Treasury Board and the Public Service Alliance of Canada, Lightkeepers (supervisory and non-supervisory) (Expiry 31 December 1972), and Agreement between the Treasury Board and the Professional Institute of the Public Service of Canada, Agriculture (all employees) (Expiry: 4 July 1971). ${ }^{8}$ Canada, Guidelines on the Grievance Procedure (Draft), online: Treasury Board Secretariat of Canada $<$ http://www.tbs-sct.gc.ca/pubs_pol/hrpubs/TBM_11B/ggp-ldpg01-eng.asp>.
} 
administrative legal protections — at least in practice. The quasi-judicial nature of the procedure requires management to act with regard for due process, under statute and at common law. However, because the process is often administered by untrained or unqualified managers or human resources advisors, the proceedings are often conducted haphazardly and in violation of the grievant's rights. The result is both clear and appalling: Not only is the grievance system ineffective, it is prejudicial against the employee.

A number of reasons may explain why a system, fraught with so much error, has survived for almost half a century. However, it is the following reason that has compelled me to write this short paper. As one jurist aptly observes, grievance resolution in the public sector is a topic of study that has been neglected by academics. "While there have been some descriptions of rights arbitration in the public sector, there has been little in the way of analysis of the process and jurisprudence." ${ }^{99}$ It is my hope that this paper will initiate a meaningful dialogue not only in academic circles, but more importantly within the Government of Canada and the federal public service unions.

This paper is divided into six parts. I begin my analysis in part two by examining the structure, values, and goals of the private sector grievance procedure. Drawing from these values and goals — as the federal government did in 1967 when it created a procedure for the public service - I then evaluate the unique role of the Government of Canada in the administration of the grievance procedure under the Public Service Labour Relations Act. I argue that although it is desirous to administer the procedure with a great deal flexibility and collegiality, because of the government's dual role — as management and administrative decision-maker — it is impossible to

\footnotetext{
${ }^{9}$ See e.g. Katherine Swinton in Gene Swimmer \& Mark Thompson, eds. Conflict or Compromise: The Future of Public Sector Industrial Relations (Montreal: The Institute for Research and Public Policy, 1984) at 343.
} 
do so. Accordingly, the expected outcomes of the grievance procedure, as administered in the private sector, cannot be achieved. In part three, I examine the government's obligations to administer its grievance procedure in a manner congruent to the principles of natural justice and procedural fairness. In examining these principles, I turn to Canada's quasi-constitutional statute, as well as the common law in order to inform my analysis. I argue that because of the government's dual role, it is inherently biased and should be disqualified from taking decisions unilaterally. In part four, I examine what I coin to be "residual problems" in the grievance procedure. Among other things, I argue that because of the government's status as an administrative decision-maker, the grievance procedure essentially duplicates the work of the Public Service Labour Relations Board. In part five, I provide three alternatives to the model currently used by the government. All three alternatives offer conflict resolution through a procedurally fair process. Finally, I conclude by reiterating that the current system for grievance resolution in the federal public service is inadequate. If administered correctly and with a view to administrative law principles, the system is inherently biased against the employee. Adopting an effective alternative approach will not only save the government money, it will also promote harmonious industrial relations.

\section{The Grievance Procedure}

It is no surprise that the grievance process has become an integral part of the modern day collective bargaining regime. After all, "before the advent of collective bargaining, grievances were disposed of on the employer's terms, if not also at [its] pleasure or convenience." ${ }^{10}$ First adopted by the U.S. National War Labor Board ${ }^{11}$ during the Second World War, the process was recognized as being capable of influencing a variety of labour-management outcomes, including

\footnotetext{
${ }^{10}$ Ronald M. Snyder, Collective Agreement Arbitration in Canada, 4th ed. (Markham: LexisNexis, 2009$)$ at 57.

${ }^{11}$ Although this agency formed part of the executive branch of government, it was comprised of representatives from both the business and labour sectors to arbitrate disputes between workers and employers in the private sector.
} 
productivity, and product quality. ${ }^{12}$ By the end of the war, this recognition had become widespread, as grievance procedures were commonplace in the steel refining, textiles, petroleum, and aircraft industries. ${ }^{13}$ And, while productivity and product quality remain principal considerations for implementing a grievance procedure, other important values animate the process. Flexibility, timeliness, fairness, and collaboration help ensure an effective, party-owned procedure. ${ }^{14} \mathrm{I}$ begin this section by examining the importance of these values at all stages under the grievance model commonly used in the private sector. I argue that they are an integral part of the procedure, not only for resolving the grievance at hand, but also for promoting harmonious industrial relations, and contributing to the efficient operations of the enterprise, owned and managed by the employer. Using the private sector model as a reference, I will then outline the grievance procedure under the Public Service Labour Relations Act. Although it undoubtedly shares many of the goals of the private sector model, it does not, in many circumstances, share the same values. Accordingly, when the modified model is applied in the federal public service, the goals of the private sector model cannot be achieved.

\section{a. Private sector model}

Like other facets of the private sector collective bargaining regime, the grievance procedure negotiated between the employer and the union is approached with a high degree of contractual freedom. Neither Parliament nor the provincial legislatures provide guidance or direction with respect to a specific process. In fact, the Canada Labour Code ${ }^{15}$ and the Ontario Labour

\footnotetext{
${ }^{12}$ Duane, Michael J. The Grievance Process in Labor-Management Cooperation (Westport: Quorum Books, 1984) at 64 .

${ }^{13}$ Ibid.

${ }^{14}$ See e.g. David C. Elliot \& Johanne H. Goss, Grievance Mediation: Why and How it Works (Aurora: Canada Law Book, 1994).

${ }^{15}$ R.S.C. 1985 , c. L-22.
} 
Relations $A c t^{16}$ are almost silent on the issue. They merely refer to $a$ procedure in a number of different contexts. Thus, while the private sector grievance model provides a framework from which to work, the procedure adopted from workplace to workplace will depend entirely upon the negotiated text of each bargaining unit's collective agreement. That being the case, most grievance procedures operate in a multi-step fashion, and specify, for example, the: types of issues that may grieved; timeframes in which a grievance may be filed; and the classes of persons that are entitled to file. It is important to note that the flexibility in this process is geared towards resolving disputes in a collaborative and informal environment. In order to foster collaboration, the proceedings are most often confidential. Confidentiality is viewed as an important factor that influences the participants' trust and confidence in the integrity of the system. ${ }^{17}$ Moreover, to encourage bilateral collaboration, participants must agree not to use any information gained during the process in any external forum, such as arbitration.

A typical grievance procedure, as found in the private sector, comprises four key levels or steps. The first level consists of two stages. First, the aggrieved employee, with or without the union steward present, discusses his or her complaint with the first-line supervisor. At this stage, the goal is to resolve the problem as quickly and as informally as possible. However, if manager and employee are unable to reach agreement, the complaint is reduced to writing. Once submitted to management, it technically becomes a grievance. Within the timeframe specified in the collective agreement, management issues a decision, which may be challenged by the union steward or the grievant at the next level.

\footnotetext{
${ }^{16}$ S.O. 1995 , c. 1.

${ }^{17}$ Supra note 14.
} 
At the second level, the grievance is presented to an industrial relations representative (designated by management) by the union steward or, in some cases, a member of the grievance committee. The committee is typically comprised of the local union president or his or her designate, the chief steward, and usually one or two elected members. At this stage, the participants are very familiar with the collective agreement and with grievance precedent. Decisions on second-level grievances are rendered in writing by the industrial relations representative, and challenges to that decision must be made within the specified timeframe.

Grievances that are taken to third level most often involve issues that have precedent-setting ramifications, major cost implications, or broad application with the company's operations. Due to the importance of these grievances, additional management and union personnel are added to the deliberations, including the industrial relations manager and other management officials, such as a general foreman or plant superintendent, along with high-level union officials. ${ }^{18}$ If a grievance is not resolved, it can be submitted to a neutral third party — an arbitrator, who hears evidence from both sides and renders a decision, which is final and binding upon the parties. The decision is a written document submitted to the appropriate management and union officials. Its elements usually consist of the following: a statement of the issues; a statement of the facts surrounding the grievance; identification of management and union representatives involved in the matter; relevant collective agreement provisions; summaries of the union and management positions; discussion and justification for the decision; and the award. ${ }^{19}$ The arbitrator's decision need not favour a particular party. Indeed, compromise awards are often

\footnotetext{
${ }^{18}$ Supra note 12.

${ }^{19}$ Ibid.
} 
delivered. What is important, however, is that the arbitrator must demonstrate a thorough understanding of all the facts and contentions raised in the hearing. ${ }^{20}$

As noted above, the grievance process serves purposes other than simply resolving the case at hand. Meetings at the third level, for example, provide new union officials with a means of onthe-job training. Furthermore, when senior-level management and union officials participate in the process, "they serve as buck-passing devices for the union steward in the event that the grievance is not resolved in favour of the grievant." ${ }^{21}$ Lastly and perhaps most importantly, this level serves as a therapeutic mechanism for the grievant, who may simply wish to express discontent to senior levels of management. ${ }^{22}$ This last purpose can function as a device that not only detects problems that are common among subunits, but identifies individual subunits that require special attention. ${ }^{23}$

\section{b. Federal public service model}

The grievance procedure used by the federal public service bears a remarkable resemblance to that used by the private sector. After all, it should, the public service grievance procedure takes its roots in industry. ${ }^{24}$ The most notable similarity between the two procedures is its structure. ${ }^{25}$ Akin to the private sector, the Government of Canada has adopted a multi-step grievance process. However, despite the appearance of an almost identical system, there are a few key distinctions. Unlike the process negotiated in the private sector, the public sector grievance procedure is almost entirely legislated - leaving the government and the unions with very little to

\footnotetext{
${ }^{20}$ Ibid.

21 Ibid.

${ }^{22}$ Ibid.

${ }^{23}$ Ibid.

${ }^{24}$ Canada, Report of the Preparatory Committee on Collective Bargaining in the Public Service (Ottawa: Queen's Printer, 1965) at 38 (Chair: A.D.P. Heeney).

${ }^{25}$ Caron, Renée. Employment in the Federal Public Service, looseleaf (Aurora: Canada Law Book, 2001).
} 
discuss during contract negotiations. Part two of both the Public Service Labour Relations Act ${ }^{26}$ and Public Service Labour Relations Board Regulations, ${ }^{27}$ for example, regulate a great deal of the grievance procedure. So while the collective agreements ${ }^{28}$ of the various public service unions include provisions relating to the grievance procedure, they address the less substantive and more procedurally-focussed aspects of the process. For the most part, the agreements restate the issues outlined in the Act and Regulations, which include but are not limited to the: types of issues that can be grieved; process for referring a grievance to adjudication; and the binding effects of grievance decisions on the parties. This difference has a profound effect on the goals and outcomes of the process. For starters, the process is no longer party-owned. The government unilaterally imposes its wishes and power on the unions and employees-eliminating an element of flexibility both at the bargaining table and during the grievance process.

Moreover, the system that the government has created carves out a unique and untenable position for management. Because management is also the government, it becomes, de facto, an "administrative decision-maker," making the process more akin to arbitration. The process is, more often than not, administered in a hearing-like manner, and often by an unqualified manager or labour relations advisor. Accordingly, the process changes from a collaborative to an adversarial model. Instead of working together to devise solutions, management and the employee are working against each other in their own interests - further creating distance between each other and adding a layer of unneeded and undesired formality. The government's

\footnotetext{
${ }^{26}$ S.C. 2003 , c. 22.

${ }^{27}$ S.O.R./2005-79.

${ }^{28}$ See e.g. Agreement between the Treasury Board and the Public Service Alliance of Canada, Program and Administrative Services (Expiry: 20 June 2014) and Agreement between the Treasury Board and the Canadian Association of Professional Employees, Economics and Social Science Services (Expiry: 21 June 2011).
} 
dual also role raises serious issues of procedural fairness; I will address these issues in the section that follows.

The formal qualities of the public sector grievance procedure extend beyond the four walls of the room in which the grievance is being heard. Unlike the informal document used to file a grievance in the private sector, the language of which can be quite loose, the "Federal Court has not been as lenient in allowing [grievants] latitude in drafting their grievances. [Grievants] are, instead, expected to be fairly specific in stating the grounds on which they are basing their grievances (as well as the remedy sought)." ${ }^{29}$ This distinction is important because it means that it would be wise for the public sector grievant to seek qualified counsel, legal or other, in drafting his or her grievance. Further, because not every grievance that is filed may be referred to adjudication, it is even more important that the grievance be well-crafted. In fact, section 209 of the Public Service Labour Relations Act considerably limits the Public Service Labour Relations Board's jurisdiction to matters relating to the interpretation or application of a provision of the grievant's collective agreement, and some forms of disciplinary action. ${ }^{30}$ Thus, the employee is barred from bringing a claim to the Board with respect to the application of any piece of federal legislation, or policy issued by the Government of Canada — of which there are hundreds. Employees are also expressly prohibited from commencing a civil action against the government. The Public Service Labour Relations Act rids an employee of the right to sue the government in court, and grants an employee the right to grieve in its very own form of kangaroo court in its stead. ${ }^{31}$ The grave implications of this provision are even more reason for an

\footnotetext{
${ }^{29}$ Christopher Rootham, Labour and Employment Law in the Federal Public Service (Toronto: Irwin Law, 2007) at 281.

${ }^{30}$ Note that this language is also captured in various collective agreements, supra note 19.

31 Supra note 5 at s.236 (1).
} 
employee to have expert counsel, and for the appropriate procedural protections built into the grievance process.

The final level of the public sector model also resembles the final level of the private sector process. However, instead of the matter being referred to a private, third-party arbitrator, the grievance may, in some instances, be referred to the Public Service Labour Relations Board. The Board is independent of management, and like most other labour relations boards, the Public Service Labour Relations Board has a strong privative clause embedded in its constituent legislation. Thus, a court will rarely be inclined to overturn a decision taken by the Board.

It is also important to note that in addition to the formal process itself, "there is a bewildering array of mechanisms for resolving disputes between individuals and the employer." ${ }^{32}$ As I will discuss in greater detail below, the Public Service Labour Relations Act requires every deputy head to institute an "informal conflict management system." ${ }^{33}$ However, the Act provides no guidance as to what the system should comprise. The result is a complex system that is often poorly administered and difficult to understand.

\section{Management's plight as administrative decision-maker in the federal public service grievance procedure}

The Government of Canada plays a unique role in the administration of its grievance procedure. It not only acts as legislator and management, but also as administrative decision-maker. In other words, the government becomes a quasi-judicial body "before which, a matter may be heard or

\footnotetext{
${ }^{32}$ See Fryer Report, supra note 6 at 28.

${ }^{33}$ Supra note 5 at s.207.
} 
tried, as distinguished from a purely executive agency." ${ }^{34}$ Section 214 of the Public Service Labour Relations Act carves out this distinctly unique role for the government. It reads:

If an individual grievance has been presented up to and including the final level in the grievance process and it is not one that under section 209 may be referred to adjudication, the decision on the grievance taken at the final level in the grievance process is final and binding for all purposes of this Act and no further action under this Act may be taken on it.

If section 214 reads like a privative clause, that is because it is. Although on its face, this section does not explicitly provide the government with administrative decision-making status, it does suggest that the decision taken on the grievance at the final level of the procedure will be insulated from review by the judiciary. ${ }^{35}$ This type of clause is a common feature in legislation establishing administrative boards and tribunals, and is, in fact, unique to such bodies. So while Parliament had intended to limit judicial interference in the government's grievance procedure through the phrase "final and binding," it conferred administrative decision-making power to management, at the same time. As a result, the procedural protections that apply to all administrative bodies under statute and at common law must also apply throughout every stage of the federal public service grievance process.

Among other things, administrative agencies must act with fairness, impartiality, and adjudicative independence; and now, so too must management. In this section, I will examine the role of these principles, as applied to the public sector grievance procedure, under the Canadian Bill of Rights, ${ }^{36}$ and at common law. Although they aim to protect the sanctity of an administrative process, they inevitably work counter to the principles of flexibility and

\footnotetext{
${ }^{34}$ Black's Law Dictionary, 8th ed., s.v. "administrative tribunal".

${ }^{35}$ See Richard J. Charney \& Thomas E.F. Brady, Judicial Review in Labour Law, (Aurora: Canada Law Book, 2007).

${ }^{36}$ S.C. 1960 , c. 44.
} 
collaboration that underpin the private sector grievance process. Thus, while management is required to be unbiased, fair, and independent in its decision-making process, it rarely adheres to such requirements-leaving the grievant in an untenable situation. If management, on the one hand, administers the grievance procedure according to the private sector model's principles of flexibility and collaboration, the grievant is denied his or her due process rights. On the other hand, if management administers the process in accordance with the administrative law principles noted above, the grievant is robbed of the benefits of a collaborative and informal grievance procedure. And even if the grievance procedure were administered in a manner akin to an administrative tribunal, it is impossible for government, in its management capacity, to remain unbiased and independent. The result is unsatisfactory for all parties.

\section{a. Due process and fairness accorded by the Canadian Bill of Rights}

Due process rights are deeply engrained in the common law, and in Canada are given explicit protection under the Canadian Bill of Rights. The principal procedural protections in the Canadian Bill of Rights are found in section 2 (e):

Every law of Canada shall, unless it is expressly declared by an Act of the Parliament of Canada that it shall operate notwithstanding the Canadian Bill of Rights, be so construed and applied as not to abrogate, abridge or infringe or to authorize the abrogation, abridgement or infringement of any of the rights or freedoms herein recognized and declared, and in particular, no law of Canada shall be construed or applied so as to ... deprive a person of the right to a fair hearing in accordance with the principles of fundamental justice for the determination of his rights and obligations.

The guarantee of a "fair hearing in accordance with the principles of fundamental justice for the determination of [one's] rights and obligations" has been construed to guarantee procedural rights. As Professor Hogg observes, "the term fundamental justice [is] equivalent to natural justice, a term that does have an established meaning in Anglo-Canadian law. The rules of 
natural justice are rules of procedure only: they require a hearing, unbiased adjudication and (a recent development) a fair procedure." ${ }^{37}$ Thus, every grievant who files a grievance under the Public Service Labour Relations Act is entitled to an unbiased adjudicator and a fair proceeding. If management is the sole decision-maker on any number of issues that may be grieved, it will be inherently biased. In other words, it will be impossible for one manager to render an unbiased decision relating to an act or omission of another member of the management team, because that manager will always have an unequivocal interest in the case being tried. Therefore, management's decision at every level of the grievance procedure should be declared invalid for want of an impartial adjudicator.

Moreover, in order for a process to be conducted in a procedurally-fair manner, parties have to be apprised of the exact manner in which the process is to be conducted. As such, most adjudicative bodies issue rules of procedure or practice. ${ }^{38}$ This not only provides parties and their counsel with advance guidance as to how the proceeding will unfold, but it ensures standardization and predictability from proceeding to proceeding. As I will discuss below, at present, even if one department or agency were to institute such rules, there is no requirement for another department or agency to issue the same - if it issues them at all. Therefore, the grievant is unlikely to know how the procedure will be adjudicated until the time of adjudication. This clearly falls short of the fair procedural requirements espoused by the Canadian Bill of Rights.

\section{b. Bias and independence}

In addition to the Bill of Rights, the common law also imposes a duty of fairness on adjudicative decision-makers. This duty requires the decision-maker to perform his or her function "free both

\footnotetext{
${ }^{37}$ Peter W. Hogg, Constitutional Law of Canada, 5th ed. (Toronto: Carswell, 2007) at 47-20.

${ }^{38}$ See e.g. Public Service Staff Relations Board Regulations and Rules of Procedure, S.O.R./93-348 and Ontario, "Rules of Procedure" Ontario Labour Relations Board (1 April 2012), online: OLRB

$<$ http://www.olrb.gov.on.ca/english/Rules_of_Procedure_2012.pdf $>$.
} 
from material interest in the outcome, and from bias or reasonable apprehension from it." ${ }^{39}$ As noted above, the government has an inherent interest in the outcome of every grievance that appears before it. Because the government is both management and decision-maker, it is impossible to separate its interests from the process, at least under the present model. Indeed, "an administrative decision-maker who is an employee or officer of a party is likely to be disqualified for reasonable apprehension of bias on the ground of pecuniary interest or lack of independence." And, "where a decision-maker is in the position of reviewing a decision made earlier by his superior, a reasonable apprehension of bias will also be found." ${ }^{40}$ The common law is clear, if not explicit, on this issue. All employers, including the government, are unable to render an unbiased decision relating to its employees; hence the independence requirements of the third-party arbitrator in the private sector grievance model, and the Public Service Labour Relations Board in the public sector procedure.

The maxim "nemo judex in causa sua" need also be applied to all adjudicative decision-makers at common law. It stipulates that no one shall be a judge in his or her own cause and "encompasses both a decision-maker who has a pecuniary interest in the outcome of a decision and a non-pecuniary interest in a particular outcome." ${ }^{41}$ Although the government may not, in every instance, have a pecuniary interest in the outcome of the process, it will, by virtue of its dual role, always have non-pecuniary one. However, there are many circumstances in which the government will have a pecuniary interest, as many grievances are filed because of a dispute over some financial benefit. For these reasons alone, the government, as adjudicative decisionmaker, cannot fulfill its common law duties.

\footnotetext{
${ }^{39}$ Donald J.M. Brown \& John M. Evans, Judicial Review of Administrative Action in Canada, looseleaf (Toronto: Canvasback Publishing, 2011) at 11-1.

${ }^{40}$ Ibid. at 11-41.

${ }^{41}$ Ibid. at 11-28.
} 
In 1995, the Supreme Court of Canada began imposing the same requirements upon adjudicative decision-makers as it did the judiciary. Since then, the Court has held that a "reasonable apprehension of bias may arise from the fact that the financial security, tenure, or career of a decision-maker might be adversely affected if the dispute were decided one way rather than another." ${ }^{42}$ As Laskin C.J.C. held in Canadian Pacific Ltd. v. Matsqui Indian Band:

I agree and conclude that it is a principle of natural justice that a party should receive a hearing before a tribunal which is not only independent, but also appears independent. Where a party has a reasonable apprehension of bias, it should not be required to submit to the tribunal giving rise to this apprehension. Moreover, the principles for judicial independence outlined in Valente are applicable in the case of an administrative tribunal, where the tribunal is functioning as an adjudicative body settling disputes and determining the rights of the parties. ${ }^{43}$

The Government of Canada does not, at present, afford management any semblance of financial security, or security of tenure. Accordingly, managers in a decision-making capacity may feel compelled to render a decision in favour of the government. Moreover, it is very conceivable for the decision-maker to be influenced either by his or her superiors or colleagues. Thus, the standard of institutional independence required of the judiciary cannot be met.

And, "where a tribunal does not satisfy the standard of institutional independence, every member will be disqualified from adjudicating a dispute." ${ }^{44}$ Of course, if the statute itself establishes the tribunal's relationship with the government, and its terms of reference, the lack of institutional independence will not invalidate the tribunal's decisions unless it conflicts with the quasiconstitutional guarantee of the right to a fair hearing before an impartial and independent decision-maker. ${ }^{45}$ However, the Public Service Labour Relations Act does not contain any such

\footnotetext{
${ }^{42}$ Ibid. at 11-22.

${ }^{43}$ [1995] 1 S.C.R. 3.

${ }^{44}$ Supra note 29 at 11-24.

${ }^{45}$ Ibid.
} 
provision, and therefore the government cannot be relieved of its common law duty to provide a hearing that is independent.

\section{c. Reasons}

The specific content of "procedural fairness" and "due process" in Canada has been formulated through interpretations of the common law, the Canadian Charter of Rights and Freedoms, ${ }^{46}$ and the Bill of Rights to include reasons for a decision. Writing for a majority in the watershed case Baker v. Canada (Minister of Citizenship and Immigration), L'Heureux-Dubé, J. held that:

Reasons, it has been argued, foster better decision making by ensuring that issues and reasoning are well articulated and, therefore, more carefully thought out. The process of writing reasons for decision by itself may be a guarantee of a better decision. Reasons also allow parties to see that the applicable issues have been carefully considered, and are invaluable if a decision is to be applied, questioned, or considered on judicial review. Those affected may be more likely to feel they were treated fairly and appropriately if reasons are given. ${ }^{47}$

In many cases, reasons or reasonably intelligible reasons do not accompany a decision. This may be due, in part, to the inexperience of the decision-maker or the human resources officer advising the decision-maker. Most publically-appointed adjudicative decision-makers receive training on the types of duties that are required of the position, including the drafting of reasons. This training, when combined with previous knowledge (either as a professional labour relations officer or lawyer) and practice, helps ensure the delivery of sound reasons. The same is not the case in the public sector grievance procedure. Very often, adjudicative decision-makers are tasked with such responsibility and are provided no formal training. Furthermore, management's adjudicative decision-making responsibilities are likely to be tertiary. Therefore, it is very likely

\footnotetext{
${ }^{46}$ Canadian Charter of Rights and Freedoms, Part I of the Constitution Act, 1982, being Schedule B to the Canada Act 1982 (U.K.), 1982, c.11.

${ }^{47}$ [1999] 2 S.C.R. 817.
} 
that the manager will have no experience drafting reasons. This invites unnecessary error into a process already fraught with it.

\section{Residual problems with the public service grievance procedure}

Aside from the procedural concerns, discussed above, a number of other issues give rise to the federal public service's ineffective grievance process. Although these issues are residual to the more serious and pressing concerns of fairness and natural justice, they too impact the effectiveness of the process.

\section{a. Lack of standardization}

The birth of "public service modernization" conferred an unparalleled level of autonomy upon deputy heads of federal departments and agencies. In response to the recommendations made by the Auditor General in the year 2000, ${ }^{48}$ Parliament had aimed to streamline human resources governance through the enactment of the Public Service Modernization Act. ${ }^{49}$ Along with several other changes, the Act shifted accountability for the grievance process from the Treasury Board Secretariat to the deputy heads of the some 200 departments and agencies that comprise Canada's federal government. While the shift was intended to institute what was a greatlyneeded sense of efficiency, it did not come without its own problems. Indeed, the shift of accountability no longer meant that the grievance procedure would be standardized from department to department. Of course, the process is, to some degree, standardized for the text of the Public Service Labour Relations Act and regulations thereto provide uniformity. However, the manner in which departments and their staffs approach the procedure can differ significantly.

\footnotetext{
${ }^{48}$ Treasury Board of Canada Secretariat, Report of the Review of the Public Service Modernization Act, 2003 (Ottawa: Department of Public Works and Government Services, 2011) at 104.

${ }^{49}$ S.C. 2003 , c. 22 .
} 
At first glance, this shift would appear to conform to the principle of flexibility espoused by the private sector grievance model. A deeper analysis, however, yields otherwise. Because deputy heads can issue their own policies and directives with respect to the administration of the grievance procedure, it is not inconceivable for some departments to institute a policy to deny claims without attending to their merits. Such polices would go relatively unnoticed because very little data is collected about the administration of the grievance procedure in the federal public service. ${ }^{50}$ This undoubtedly raises many of the same issues of fairness and bias that I addressed, above. It also raises issues of fairness in another context. If public servants of the same bargaining unit are employed at different departments, as many are, should they not be entitled to be treated (and have their grievances administered) in a like manner? The answer is obvious: yes. In fact, while the Public Service Modernization Act accords deputy heads with great deal of autonomy and flexibility in the administration of the public service grievance procedure, they are contractually obligated, under the various collective agreements, to administer the process uniformly. Not only is this a legitimate expectation, it is the purpose of collective bargaining. Having a centralized policy or community of practice helps to ensure that the grievance procedure is administered in a uniform and fair manner. A centralized body would also be wellsuited to collect relevant data on the grievance procedure, so that it may respond to the types of procedural issues that have been identified throughout this paper.

Moreover, under the public service grievance system, a decentralized procedure invites the possibility of conflicting decisions on similar issues. While the common law principle of stare decisis is not observed by most Canadian labour tribunals, the Public Service Commission

\footnotetext{
${ }^{50}$ Supra note 41.
} 
Advisory Council's Working Group on Recourse notes that like cases should be treated alike. ${ }^{51}$ As it stands, the grievance decisions that are issued by management in the some 200 departments and agencies are confidential and are therefore not published. Thus, there is no way of ensuring consistency in management decision-making at any level during the grievance procedure. Publishing decisions would not only provide precedential value but would also provide predictability and standardization in an otherwise incongruent system.

\section{b. Access to information}

An aggrieved party wishing to build his or her case can seek information from the government in two ways. First, he or she can request the information through the appropriate channels. However, in many instances, the grievant is unlikely to do so, either for fear of reprisal, or of escalating the conflict. And, because the grievance system is adversarial, the department or agency in which the grievant is employed may not wish to disclose the information requested. It is important to note that the government has no obligation to disclose any information via this route.

Of course, the aggrieved party can also submit an access to information and privacy request under the Access to Information Act ${ }^{52}$ or Privacy Act, ${ }^{53}$ respectively. Such a request may provide some anonymity, but in all likelihood the nature of the information requested would yield the information-seeker's identity. Nonetheless this is the only type of request for information to which the government is legally obligated to respond. Thus, in many cases, it may be the only feasible option to obtain information regarding his or her complaint. However, it is not without its drawbacks.

\footnotetext{
${ }^{51}$ See Report on Recourse, supra note 6 at iv.

${ }_{53}$ Access to Information Act, R.S.C. 1985, c. A-1.

${ }^{53}$ Privacy Act, R.S.C. 1985 , c. P-21.
} 
The Public Service Labour Relations Board Regulations require an aggrieved party to file a grievance within 35 days of becoming aware of the alleged violation. ${ }^{54}$ The grievant must work within this relatively narrow window to build and present his or her case, including filing a request for information. Under the Access to Information and Privacy Act, the Government of Canada has 30 days to respond to a request, ${ }^{55}$ and may be granted an additional 30 days if it so requires. ${ }^{56}$ So the aggrieved party, at best, has five days to properly build and present his or her case. Certainly, this is unfair and works counter to the spirit of the Public Service Labour Relations Act.

\section{c. Duplication of process}

The structure of the public service grievance procedure lends itself to duplication. Given that it operates in a quasi-judicial nature, it is questionable whether, under the current system, the Public Service Labour Relations Board is needed over and above the grievance process. After all, the jurisdiction of management is not only wider than that of the Board, but it captures the Board's jurisdiction in its entirety. Grievance decisions that are made at the final level are, according to section 214 of the Public Service Labour Relations Act, final and binding and can neither be appealed to a court nor the Board. Thus, the Public Service Labour Relations Board provides no added value if the grievance system operates as it should. Having two parallel systems is not only costly in a monetary sense, but also in time. However, because the system does not, in most instances, operate according to the principles of natural justice and procedural fairness, the Board acts as a very good fail-safe mechanism. And while this role is integral in the current system, Parliament never intended for it to act as such.

\footnotetext{
${ }^{54}$ Supra note 19 at s. 68 (1).

${ }^{55}$ Supra note 40 at s.7.

${ }^{56}$ Ibid. at s.9(1).
} 
Unfortunately, adjudication is not the only point at which the grievance procedure is duplicated. Indeed, given the requirement stipulated in the Public Service Labour Relations Act for every deputy head to implement an informal conflict management system, it is very possible for the grievance procedure to be overtaken at points much earlier than the adjudicative process. The informal conflict management system aims to "prevent conflict escalation by managing and resolving conflicts in the workplace quickly and constructively." ${ }^{57}$ This means, that among other things, management and employee are encouraged to resolve its differences through any number of alternative dispute resolution mechanisms, such as bilateral discussion, and grievance mediation. Although these forms of alternative dispute resolution should be integrated into an effective grievance procedure, it is unclear if they are. As the Fryer Report notes, the system is complex and confusing for the government to administer and the grievant to use. So it would appear very possible for the government's complex informal conflict management system to duplicate the grievance procedure.

\section{Alternatives}

As I have noted above, the Government of Canada finds itself in a unique and precarious position in the administration of its grievance procedure. If management administers the procedure according to the principles of natural justice and fairness, required by law, the process essentially duplicates the work of the Public Service Labour Relations Board. The employee is robbed of an opportunity and the benefit to own the process and resolve the conflict informally, at least in this setting. If management conducts the grievance procedure in accordance with the values espoused by the private sector model, i.e. flexibility and collaboration, then it circumvents key procedural requirements. In either case, the grievance process is ineffective. In this section, I

\footnotetext{
${ }^{57}$ Canada, "A Guide to the Key Elements of an ICMS in the Core Public Administration" Treasury Board of Canada Secretariat (12 August 2008), online: TBS $<$ http://www.tbs-sct.gc.ca/gui/conflgui-eng.asp $>$.
} 
outline reasonable alternatives, capable of achieving the goals and outcomes envisaged by the grievance procedure.

\section{a. A truly informal process}

The obvious alternative to the current model is to administer the grievance procedure as it was meant to be administered — in an informal and collaborative setting. Management's administrative decision-making status should be removed by eliminating the privative clause in the Public Service Labour Relations Act. Furthermore, the exclusivity clause should also be removed so that all matters that may be grieved may also be subject to adjudication. Such action will facilitate a process akin to the private sector model. It will provide the grievant with an opportunity to resolve his or her complaint through informal means. If that process is unsuccessful, the grievant can have his or her complaint heard in front of a fair and independent tribunal. The necessity to publish decisions, issued at the various level of the grievance procedure, would be eliminated because the process would be working in a collaborative and flexible manner. Most importantly, the government need not act with formality and rigor, as the process does not require it to act in accordance with the quasi-constitutional and common law principles of fairness and natural justice. This alternative is truly the grievance procedure in its purest form.

\section{b. Tripartite model}

However, given the shoddy manner in which the grievance procedure has been administered over the years, some sceptics may be critical of management's ability to embrace such an alternative. Thus, I offer a solution similar to the one recommended by the Advisory Committee on Labour Management Relations in the Federal Public Service. ${ }^{58}$ If the goal of both management and the

\footnotetext{
${ }^{58}$ See Fryer Report, supra note 6 at 5.
} 
public sector unions is to resolve conflict at its earliest stages of development, each department and agency should establish a tripartite process, at the final level. Both the grievant and management would appoint a representative to a grievance panel, which would ultimately be chaired by an impartial third party. Implementing this solution would be relatively simple, as there would be no requirement to amend the Public Service Labour Relations Act. The tripartite panel would be responsible for conducting its work in accordance with the principles of fairness and natural justice required of any adjudicative decision-maker. However, the panel would be exempt from the bias requirements of the current system. As two administrative law scholars note:

Where the function of the decision-maker is essentially adjudicative or judicial in nature, the bias requirements will be akin to those applied to judges. Nevertheless, even with this broad classification, some accommodation must be made for variations in the adjudicative process, perhaps the most familiar being the use of tripartite tribunals in connection with grievance arbitrations, the administration of labour relations regulator legislation and employment equity regimes. In these contexts, a degree of partisanship is to be expected, employer nominees bring a particular point of view to the issues, as do employee and union nominees. Indeed, in the design of the tribunal, it is the neutral chairman who provides the requisite impartiality, although all member of the board are expected to "act judicially" and to make their decisions fairly, that is upon the evidence and argument of the parties. ${ }^{59}$

The tripartite model offers both flexibility and fairness for the government and the grievant. The government could, for example, establish a roster of adjudicators, thus allowing managers to perform their primary functions while gaining valuable experience for the proper administration of the grievance procedure. And, if the union contributes to selecting the Chair, the grievant would be assured that the process was conducted with absolute impartiality and fairness.

\footnotetext{
${ }^{59}$ Supra note 39 at 11-14.
} 


\section{c. A properly administered administrative process}

Finally, the Government of Canada could administer the grievance process as an adjudicative body should, with the requisite procedural protections espoused by the Canadian Bill of Rights, and at common law. Grievance decisions and reasons for the decisions should be published—if not for precedential value than to ensure accountability. A requirement relating to the expertise of the adjudicative decision-maker should reflect that required of the Public Service Labour Relations Board. The Board should act as an appellate body so that its work is not duplicated by the grievance process. Furthermore, the Board should still hear matters that are not amenable to adjudication under the grievance process. This solution would require the least amount of work for both the government and the public sector unions to implement. Although a minor amendment would be required to grant the Public Service Labour Relations Board with the proposed appellate jurisdiction, the only real work required would be to educate management on its proper role and responsibility in conducting an adjudicative hearing.

\section{Conclusion}

Conflict is an inevitable part of every workplace; and because it is, every workplace should have an effective mechanism for resolving it. For nearly half a century, the Government of Canada has been administering a grievance system that has been widely criticized for its complexity and infectiveness. If the process is properly administered, and in accordance with the principles of fairness and natural justice, it is incapable of having a positive influence on such labourmanagement outcomes as productivity and product quality. Its formal, adversarial qualities create distance between the grievant and management, and contradict the values espoused by the private sector grievance procedure. If the process is administered according to those values, the grievant is denied his or her due process rights. In either case, the public sector grievance system 
falls short of achieving what was envisaged in 1967, and what is expected by every grievant today: A fair and constructive forum for settling rights-based disputes.

Despite the number of recommendations made to rectify the system's shortcomings, the Government of Canada has done little to effect any change. Reasonable and effective alternatives are indeed available to correct the systemic problems inherent in the process. And until one such alternative is adopted, the government will continue to administer its grievance process in a manner reminiscent of a time when the doctrine of sovereignty ruled the day. 


\section{Annex A: Bibliography}

a. Primary and Secondary Legislation

Access to Information Act, R.S.C. 1985, c. A-1.

Canadian Bill of Rights, S.C. 1960, c. 44.

Canadian Charter of Rights and Freedoms, Part I of the Constitution Act, 1982, being Schedule B to the Canada Act 1982 (U.K.), 1982, c.11.

Canada Labour Code, R.S.C. 1985, c. L-22.

Civil Service Act, S.C. 1961, c. 57.

Ontario Labour Relations Act, S.O.1995, c. 1.

Privacy Act, R.S.C. 1985, c. P-21.

Public Service Labour Relations Act, S.C. 2003, c. 22.

Public Service Labour Relations Board Regulations, S.O.R./2005-79.

Public Service Staff Relations Act, S.C. 1967, c. 72.

Public Service Staff Relations Board Regulations and Rules of Procedure, S.O.R./67-155.

Public Service Staff Relations Board Regulations and Rules of Procedure, S.O.R./93-348.

b. Jurisprudence

Baker v. Canada (Minister of Citizenship and Immigration), [1999] 2 S.C.R. 817.

Dunsmuir v. New Brunswick, 2008 SCC 9, [2008] 1 S.C.R. 190.

Reference re Remuneration of Judges of the Provincial Court of Prince Edward Island;

Reference re Independence and Impartiality of Judges of the Provincial Court of Prince Edward Island, [1997] 3 S.C.R. 3, 150 D.L.R. (4th) 577.

c. Collective Agreements

Agreement between the Treasury Board and the Canadian Association of Professional Employees, Economics and Social Science Services (Expiry: 21 June 2011).

Agreement between the Treasury Board and the Council of Graphic Arts Unions of the Public Service of Canada, Printing Operations (non-supervisory) (Expiry: 31 December 1972).

Agreement between the Treasury Board and the Public Service Alliance of Canada, Lightkeepers (supervisory and non-supervisory) (Expiry 31 December 1972).

Agreement between the Treasury Board and the Public Service Alliance of Canada, Program and Administrative Services (Expiry: 20 June 2014). 
Agreement between the Treasury Board and the Professional Association of Foreign Service Officers, Foreign Service (all employees) (Expiry: 25 March 1973).

Agreement between the Treasury Board and the Professional Institute of the Public Service of Canada, Agriculture (all employees) (Expiry: 4 July 1971).

\section{d. Secondary Materials: Monographs}

Adell et al. Labour and Employment Law: Cases, Material, and Commentary, 8th ed. (Toronto: Irwin Law, 2011).

Arthurs, H.W. Collective Bargaining by Public Employees in Canada: Five Models (Ann Arbor: The University of Michigan, 1971).

Blanpain, R., ed. Comparative Labour Law and Industrial Relations in Industrialized Market Economies (The Netherlands: Kluwer Law International, 2010).

Caron, Renée. Employment in the Federal Public Service, looseleaf (Aurora: Canada Law Book, 2001).

Charney, Richard J. \& Brady, Thomas E.F. Judicial Review in Labour Law, (Aurora: Canada Law Book, 2007).

Duane, Michael J. The Grievance Process in Labor-Management Cooperation (Westport: Quorum Books, 1984).

Elliot, David C. \& Goss, Joanne H. Grievance Mediation: Why and How it Works (Aurora: Canada Law Book, 1994).

Brown, Donald J.M. \& Evans, John M. Judicial Review of Administrative Action in Canada, looseleaf (Toronto: Canvasback Publishing, 2011).

Finkelman, Jacob \& Goldenberg, Shirley B. Collective Bargaining in the Public Service: The Federal Experience in Canada, vol. 2 (Montreal: Institute for Research and Public Policy, 1983).

Frankel, Saul J. Staff Relations in the Civil Service: The Canadian Experience (Montreal: McGill University Press, 1962).

Hodgetts, J.E. The Canadian Public Service: A Physiology of Government 1867-1970 (Toronto: University of Toronto Press, 1973).

Hogg, Peter W. Constitutional Law of Canada, 5th ed. (Toronto: Carswell, 2007).

Lordon, Paul. Crown Law (Markham: Butterworths, 1991).

MacNeil, Michael et al. Trade Union Law in Canada, looseleaf (Aurora: Canada Law Book, 2010).

O'Sullivan, J.F., ed., Collective Bargaining in the Public Services (Toronto, The Institute of Public Administration of Canada, 1973). 
Rayner, Wesley B. Canadian Collective Bargaining Law, 2d ed. (Markham: LexisNexis, 2007).

Régimbald, Guy. Canadian Administrative Law, 1st ed. (Markham: LexisNexis, 2009).

Rootham, Christopher. Labour and Employment Law in the Federal Public Service (Toronto: Irwin Law, 2007).

Snyder, Ronald M. Collective Agreement Arbitration in Canada, 4th ed. (Markham: LexisNexis, 2009).

Stanger, Howard R. "The Evolution of an Alternative Grievance Procedure: The Columbus Typographical Union No. 5 1859-1959" in Lewin, David \& Kauffman, Bruce E., eds., Advances in Industrial and Labour Relations, vol. 10 (Bingley, U.K.: Emerald Group Publishing, 2001).

Swimmer, Gene \& Thompson, Mark, eds. Conflict or Compromise: The Future of Public Sector Industrial Relations (Montreal: The Institute for Research and Public Policy, 1984).

Swimmer, Gene \& Thompson, Mark, eds. Public Sector Collective Bargaining in Canada (Kingston: IRC Press, Queen's University, 1995).

e. Secondary Materials: Articles

Begin, James Paul. The Development and Operation of Grievance Procedures in Public Employment (Ph.D. Thesis, Purdue University Department of Sociology, 1969) [unpublished].

Note, "Public Sector Grievance Procedures, Due Process, and the Duty of Fair Representation" (1976) 89 Harv. L. Rev. 752.

f. Secondary Materials: Government Policy, and Reports

Canada, Public Service Advisory Council, Recourse in the Public Service of Canada: Report of the Public Service Commission Advisory Council's Working Group on Recourse (Ottawa: Communication Group, 2001).

Canada, Public Service Staff Relations Board, First Annual Report (Ottawa: Queen's Printer, 1968) (Chair: Jacob Finkelman).

Canada, Public Service Staff Relations Board, Thirty-Sixth Annual Report (Ottawa: Department of Public Works and Government Service, 2003) (Chair: Yvon Tarte).

Canada, Public Service Staff Relations Board, Thirty-Seventh Annual Report (Ottawa:

Department of Public Works and Government Service, 2004) (Chair: Yvon Tarte).

Canada, Report of the Preparatory Committee on Collective Bargaining in the Public Service (Ottawa: Queen's Printer, 1965) (Chair: A.D.P. Heeney).

Canada, Treasury Board of Canada Secretariat, Final Report of the Advisory Committee on Labour Management Relations in the Federal Public Service (Ottawa: Communication Group, 2001) (Chair: John L. Fryer). 
Canada, Treasury Board of Canada Secretariat, First Report of the Advisory Committee on Labour Management Relations in the Federal Public Service (Ottawa: Communication Group, 2000) (Chair: John L. Fryer).

Canada, Guidelines on the Grievance Procedure (Draft), online: Treasury Board Secretariat of Canada < http://www.tbs-sct.gc.ca/pubs_pol/hrpubs/TBM_11B/ggp-ldpg01-eng.asp>.

Treasury Board of Canada Secretariat, Report of the Review of the Public Service Moderization Act, 2003 (Ottawa: Department of Public Works and Government Services, 2011).

Treasury Board of Canada Secretariat, Staff Relations: Personnel Management (Treasury Board Manual) (Ottawa: Minister of Supply and Services Canada, 1991).

g. Secondary Materials: Debates of the House of Commons

House of Commons Debates, vol. 4 (25 April 1966) at 4246 (Hon. Lucien Lamoureux).

House of Commons Debates, vol. 6 (31 May 1966) at 5791 (Hon. Lucien Lamoureux).

House of Commons Debates, vol. 6 (6 June 1966) at 6009 (Hon. Lucien Lamoureux). 
Notes 


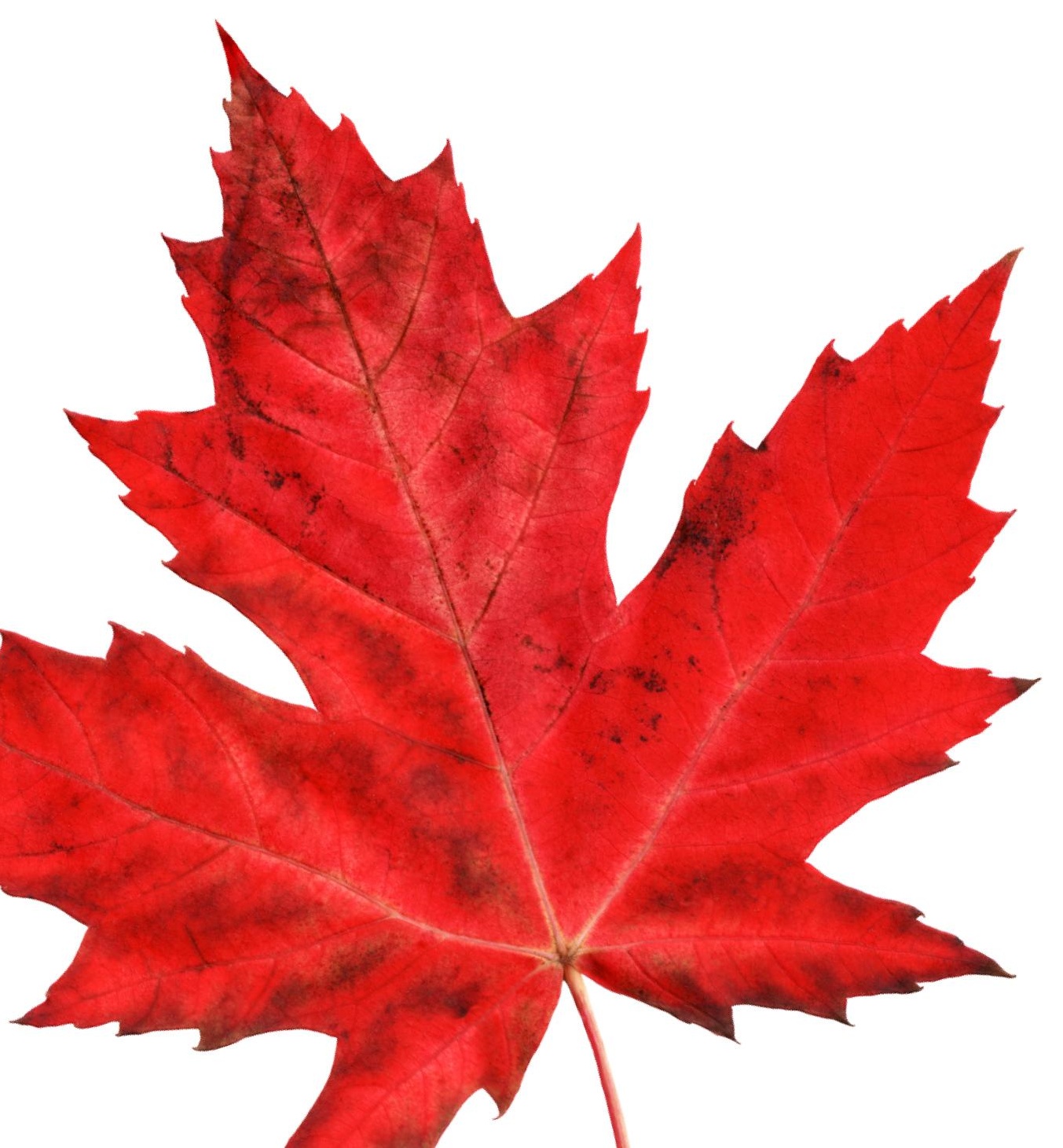

